\title{
Laryngeal Tube
}

National Cancer Institute

\section{Source}

National Cancer Institute. Laryngeal Tube. NCI Thesaurus. Code C122596.

A supraglottic airway device. 